\title{
Parochialism and Implications for Chinese Firms' Globalization
}

\author{
Jing Betty Feng \\ Farmingdale State College (SUNY) \\ fengj@farmingdale.edu \\ Leigh Anne Liu \\ Georgia State University \\ laliu@gsu.edu \\ Chunyan Jiang \\ Nanjing University \\ cyjiang@nju.edu.cn
}




\title{
Parochialism and Implications for Chinese Firms' Globalization
}

\author{
ABSTRACT \\ We explore the meaning of parochialism (xiao nong yi shi, 小农意识) to explain certain \\ paradoxical Chinese managerial behaviors. We discuss how cultural, political, and economic \\ traditions in China formed a salient context to cultivate parochialism. Qualitative data from \\ Chinese and American managers reveal that the conceptual framework of parochialism includes \\ a cognitive dimension of closed-mindedness, a behavioral dimension of self-protection, and a \\ relational dimension of in-group focused social relationship. Parochialism hampers effective \\ globalization of Chinese firms because it negatively impacts key facets of organizational culture: \\ employee development, communication, customer orientation, social responsibility, strategic \\ planning, and innovation. The study offers theoretical and practical implications for Chinese \\ management research and the development of global competence.
}

Keywords: Chinese management theory, Chinese managerial culture, managerial cognition, parochialism

Methodology: Qualitative 
As China becomes a rapidly growing economic super power worldwide, understanding Chinese organizational behaviors has both theoretical and practical significance (Leung, 2012a). Crosscultural research often explains Chinese managerial decisions and behaviors according to cultural values (e.g., Hofstede, Hofstede, \& Minkov, 2010; House, Hanges, Javidan, Dorfman, \& Gupta, 2004), but established cultural dimensions fail to explain many Chinese contradictory managerial phenomena. For example, Hofstede (2001) found Chinese culture to have high longterm orientation, while others have reported that mainland Chinese make extremely short-term, opportunity-driven, present-oriented decisions (Chen, 2001; 2002; Fischer, 2012; House et al., 2004), such as allowing quality to disintegrate and investing without due diligence (Midler, 2010). Supposedly Chinese society focuses on personal relationships (Hofstede et al., 2010; Redding, 1990), but some report that Chinese business partners are uncooperative, untrustworthy, and uncommitted (Wu, 2013). Although Chinese culture is supposed to be highly collectivist (Hofstede, 2001; House et al., 2004; Schwartz, 1999), Chinese managers might show a very utilitarian attitude toward teamwork and only engage for individually beneficial outcomes (Fischer, 2012).

Such paradoxical phenomena are often attributed to institutional factors rather than cultural perspectives (Chen, Friedman, \& McAllister, 2017; Child \& Marinova, 2014; Leung, 2014). Although indigenous Chinese management research has drawn increasing attention (Leung, 2012a), studies have failed to completely explain the disconnection between established cultural dimensions and Chinese managerial behaviors (Redding, 2014). As Chinese society becomes increasingly modernized, cultural traditions built on the philosophical and cultural heritage continue to influence current management mindset in China (Pan, Rowney, \& Peterson, 2012; Zhang, Chen, Liu, \& Liu, 2008). It is therefore essential to develop new ideas based on 
China's ecological and sociocultural context to explain paradoxical organizational behaviors (Tsui, 2012).

The purpose of this article is to qualitatively explore a conceptual framework of parochialism as a cultural mindset (Redding, 2014) and to provide an alternative view that may explain challenges facing globalization of Chinese firms (Leung, 2014). We use the term parochialism as a translation of the Chinese term xiao nong yi shi 小农意识, or “petty peasant mentality," originally applied to the rural society and deeply rooted in several thousand years of recorded history, as Fei Xiaotong described in From the Soil, the Foundation of Chinese Society: Villagers restrict the scope of daily activities; they do not travel far; they seldom make contact with the outside world; they live solitary lives; they maintain their own isolated social circle. All of these characteristics contribute to the parochialism of rural China (Fei, Hamilton, \& Wang, 1992, P 41).

We propose that parochialism is a cognitive hurdle that inhibits successful globalization for Chinese firms. Parochialism is a mindset originating from political, economic, and cultural traditions of China, based on rural authoritarianism rather than cosmopolitan egalitarianism. Parochialism is a coping and rationalizing mechanism, but when used for problem-solving it may limit collaboration, trust, and long-term vision. Although parochialism is an individual-level construct, it becomes a group-level concept especially among members of a collectivist society where individuals tend to follow opinion leaders or hierarchical superiors (Li, Leung, Chen, \& Luo, 2012). Parochialism can cause Chinese managers to make poor strategic decisions for shortterm gains that damage relationships with global partners. This shared mindset among Chinese managers, the rich flow of cash and resources, and the government push for globalization are 
potentially lethal forces in the global business environment, especially when international communities are trying to accommodate Chinese partners and investors.

We explore the conceptual property of parochialism and its impact on Chinese globalization in three sections. First, we explain the theoretical context of parochialism from the interweaving political, economic, and cultural traditions in Chinese history (Leung, 2012b). Second, based on qualitative interview data, we identify the key dimensions of parochialism and develop a conceptual framework. We then provide propositions to demonstrate how parochialism manifests in the globalization of Chinese organizations. Last, we discuss theoretical and empirical implications and boundary conditions.

\section{THEORETICAL CONTEXT}

\section{Parochialism as a Mindset}

To study parochialism in China, we must first understand its contextual foundations.

Parochialism is not a new concept in Chinese. It reflects an inglorious side of Chinese culture. Mao Zedong called it a "mental hurdle" during the contemporary revolution era (Yuan, 2012). Social science (e.g. Fairbank, 1979; Fei et al., 1992; Liang, 1987; Sun, 2004) and literary writers have well-documented traits of Chinese parochialism such as Pearl Buck's The Good Earth (1937), Lu Xun's Medicine (1919), and The True Story of Ah Q (1921). The traits of parochialism are engrained deeply in every level of Chinese society. With rapid urbanization in the last four decades, individuals who display certain thinking patterns, behaviors, and relationships are commonly criticized as showing xiao nong yi shi. Such a state of mind is pervasive, beyond income, education, or demographic groups.

Like other indigenous sociocultural phenomena such as guanxi (Chen, Chen, \& Huang, 2013; Xin \& Pearce, 1996), parochialism is complex. Chinese social scientists have defined 
parochialism as a multidimensional concept with various behavior outcomes (e.g. Deng \& $\mathrm{Li}$, 2005; Liu, 1996; 1997a; b; Yuan, 2000). Parochialism has been defined as "a cultural psychology of closed-mindedness, paranoia, conservation, submission, lack of ambition, and fear of competition（狭险偏执, 封闭保守, 逆来顺受, 不图进取, 害怕竞争的文化心理)”

(Yuan, 2000: P45). Other definitions include components of selfishness, thriftiness, restraint, hierarchy, and short-sightedness (Liu, 1996; 1997a; b). In summary, the term is widely used but loosely defined as a hierarchical and rural mindset in opposition to the egalitarian cosmopolitan culture. Before we empirically explore meanings and impacts, we next discuss China's institutional and sociocultural traditions that cultivated parochialism.

\section{Chinese Political and Economic Traditions}

In all societies, political ideologies and economic systems shape social cognitions (Jost, Glaser, Kruglanski, \& Sulloway, 2003; Jost, Napier, Thorisdottir, Gosling, Palfai, \& Ostafin, 2007; Rickert, 1998). China has undergone tremendous societal changes (Pan et al., 2012) but its mentality is still profoundly influenced by past political structures and economic systems (e.g., Kruglanski, 2013; Petty, Tormala, Brinol, \& Jarvis, 2006). For more than four thousand years, China had a centralized political system and small-scale farming economy (Needham, 1954; Redding, 2016), forming a tight social environment that encouraged parochialism (Gelfand, Raver, Nishii, Leslie, Lun, \& Lim, 2011).

When a society is highly centralized and accepts inequality, the greatest values will be placed on order, structure, mental rigidity, and closed-mindedness (Jost et al., 2003; Jost et al., 2007; Rickert, 1998). For thousands of years, China was ruled by concentrated control systems: dynasties of emperors and layers of state, provincial, city, and township governments executed power and authority (Fairbank, 1979; Redding, 2016). Confucianism, with one of its core 
messages of obedience to authority and sacrifice for social harmony, was a main philosophical resource that regulated society (Farh, Earley, \& Lin, 1997; Pan et al., 2012). Although the west values open debate, China's hierarchical system discouraged such social interaction and collective decision-making to maintain in-group harmony (Nisbett, Peng, Choi, \& Norenzayan, 2001). Such a context largely induced closed-mindedness, a state of cognitive closure and an unwillingness to be confronted by alternative opinions or external evidence (Kruglanski, 2013; Webster \& Kruglanski, 1994).

Historically, most Chinese were small-scale farmers faced with nature's vagaries and ruling class exploitation through rents, usury, or levies , finding contentment in "a wife, children, and a warm bed" (Fairbank, 1979; Yuan, 2000). They lived in self-sufficient family-based rural units and isolated circles, with limited collaboration outside their close families and neighbors and unable to experience broader social exchanges and communication (Fei et al., 1992). Attached to the land, with limited resources, individuals were constrained from exploring individual desires. Instead, they emphasized in-group sharing of limited resources. Loyalty, obedience, and hard work formed a defensive wall against insecurity and exploitation (Huang \& Bond, 2012; Redding, 1990).

\section{Relational Foundations of Parochialism}

Self-construal regulates individual perceptions, motivations, and actions (Leung, 2012b; Markus \& Kitayama, 1991). Western social structures generally feature an "organizational mode of association" (团体格局, tuan ti ge ju), in which people proactively create interrelated or independent groups. However, in China's hierarchical social structure, households are central to different circles of influence, called “differential mode of association” (差序格局, cha xu ge ju) (Fei et al., 1992: P62). Chinese society comprises embedded network circles linked through 
various social relationships. Family power determines the size of network circles: powerful families may have large circles, while poor or powerless families may have circles comprising only a few nearby members. "This notion of self amounts to egocentrism, not individualism" (Fei et al., 1992, P67). Therefore, Chinese traditionally treat in-groups and out-groups differently (Markus \& Kitayama, 1991). Western literature describes the structure as vertical collectivism (Triandis, 1995) or in-group collectivism (House et al., 2004), in which individuals have obligations, responsibilities, and interdependence with in-group members but compete with outgroup members.

To the Chinese, the "self" is defined according to interwoven relationships and reciprocal obligations among in-group members (Fairbank, 1979; Markus \& Kitayama, 1991) and less concern about out-group community, public welfare, or common interests (House et al., 2004). "Selfishness" and bystander inaction are even considered ethical and moral (Fei et al., 1992). As the proverb attests, "Each person should sweep the snow from his own doorsteps and should not fret about the frost on his neighbor's roof." Chinese are more likely to deny that communal behaviors such as littering are "bad" (Lalwani, Shavitt, \& Johnson, 2006; Sedikides, 2012) and to eschew civil participation because "selfishness drives out social consciousness" (Fei et al., 1992: 61). Thus Chinese tend to clearly distinguish between in-group and out-group circles: empathy, trust, collaboration and harmony are reserved for in-group members (Chen, Chen, \& Xin, 2004; Huff \& Kelley, 2003); out-group members draw hostility (Song, Cadsby, \& Bi, 2012; Zhang, Liu, \& Liu, 2015).

In conclusion, China's long-lasting political, economic, and cultural traditions formed a unique and tight ecological and sociocultural context that shaped social cognitions (Gelfand et al., 2011; Huang \& Bond, 2012). Parochialism became a collective coping mechanism for 
assuring security and managing uncertainty in hierarchical, isolated, and unpredictable environments. The mindset, as a phenomenon of cultural psychology, was developed in the past but conveyed to a large proportion of Chinese generations through family, education, organizations, and society. When faced with limited information in complex situations, Chinese are likely to turn to parochialism as a psychological mechanism to justify decision-making. To study parochialism as a collective mindset, we conducted a qualitative study to explore the conceptual dimensions and consequences of parochialism as Chinese firms going abroad.

\section{METHODS}

\section{Research Context and Data Collection}

Social mentality can supplement values and beliefs to determine how individuals behave in specific situations (Fischer, 2012). We propose that parochialism is an individual-level mindset that will impact organizational-level outcomes. Hence, when key decision-makers collectively have parochialistic mindsets, they will use parochialism on behalf of their organizations (Barr, Stimpert, \& Huff, 1992; Huff, 1990). We apply parochialism in the context of Chinese organizations and examine how it impacts the globalization of firms.

Qualitative methods are well-suited for examining parochialism, an emerging research subject with little or no previous theory (Myers, 2011). For the exploratory nature of this study, we adopted an interpretative approach combining grounded theory and content analysis (Cho \& Lee, 2014; Eisenhardt, 1989; Strauss \& Corbin, 1998). We conducted seventeen face-to-face interviews with managers and executives from both the United States and China. In the eight U.S. interviews, some interviewees were from organizations that directly worked with Chinese companies, such as business associations, law firms, or news media; others worked in Chinese companies located in the United States. Nine of the interviewees in China were managers or 
executives from foreign or state-owned companies across several industries. The U.S. interviews were conducted in English; the China interviews were conducted in Chinese and then transcribed and translated into English. Each interview lasted 30 minutes to an hour. Table 1 summarizes interviewee profiles.

\section{INSERT TABLE 1 ABOUT HERE}

\section{Data Analysis}

In the early phase of study, we used the grounded theory approach to allow original and rich findings to emerge and to generate new concepts and theories from qualitative data (Myers, 2011). We followed the interpretive tradition to understand parochialism effects in organizational settings (Orlikowski, 2000; Strauss \& Corbin, 1998). The interpretive approach is built on the ontological assumption that humans socially construct the world according to their understandings. The aim is to understand contexts rather than to derive deductive explanations (Myers, 2011). We analyzed and compared continuing themes and concepts to refine insights and develop conceptual categories (Corley \& Gioia, 2004; Strauss \& Corbin, 1998) through an iterative process of moving between the data, emerging constructs, and previous literature (Eisenhardt, 1989; Molinsky, 2013).

The theme of parochialism emerged when the first author was conducting semi-structured face-to-face interviews to study how Chinese firms were adapting cross-culturally in foreign environments. Interviews with American and Chinese executives and managers raised questions about interactions between Chinese and American business leaders. For example, why do the Chinese distrust one another? why would a Chinese supplier substitute cheaper material? If 
Chinese love natural beauty, why do they litter? why would a Chinese owner invest in real estate but not in product development and marketing?

The initial response to those behaviors was the consequences of the cultural differences between American and Chinese. However, the well-known cultural value dimension, such as Hofstede (2001) could not explain those behaviors. The authors iteratively shifted back and forth between the raw data and the patterns to explore various Chinese management theories such as hierarchy/power distance (Hofstede, 2001), face/ren qing (Cheung, Leung, Fan, Song, Zhang, \& Zhang, 1996; Ho, 1976), and holistic thinking (Nisbett, 2004; Nisbett et al., 2001). At that point, the concept of parochialism surfaced to explain the divergent and paradoxical behaviors of Chinese managers, greatly inspired by the sociology literature from China on xiao nong yi shi (Yuan, 2000) and Chinese rural society (Fei et al., 1992). Following the grounded theory data analysis process, we used NVivo to conduct the initial coding based on first-order themes, organized into second-order categories, and then distilled into aggregated dimensions for the overarching theoretical framework of parochialism (Charmaz, 2006; Gioia, Corley, \& Hamilton, 2013).

Armed with the initial conceptual ideas that emerged from the early phase of the study, we conducted nine structured face-to-face interviews with managers located in China. We informed them that our research purpose was to study impacts on general organizational behaviors from xiao nong yi shi, a term used in Chinese daily life. All interviews were conducted in Chinese and then translated into English. The data analysis evolved to content analysis when we used the coding categories defined in the early phase of data analysis (Cho \& Lee, 2014) by drawing on the organizational cultural framework from Tsui (2006). During the coding process, we further enhanced the conceptual model of parochialism based on evidence from our interview 
data. The interactive data analysis approach allowed us to compare the findings with similar and contradictory literature, establish coding schemes, and identify theoretical development opportunities (Miles \& Huberman, 1994).

\section{CONCEPTUAL FRAMEWORK OF PAROCHIALISM}

The interviewees in China recognized the concept of xiao nong yi shi, suggested definitions of parochialism, and confirmed that parochialism inhibits growth (Table 2).

\section{INSERT TABLE 2 ABOUT HERE}

Individuals apprise situations according to their specific knowledge structures or mindset (Liu, Friedman, Barry, Gelfand, \& Zhang, 2012). Mindsets are often multidimensional (Levy, Beechler, Taylor, \& Boyacigiller., 2007; Liu, Friedman, Barry, et al., 2012). Two waves of interview and data coding revealed three interrelated dimensions of parochialism. We labeled the cognitive dimension as closed-mindedness and the behavioral dimension as self-protection. The relational dimension was connected to both closed-mindedness and self-protection. The data showed distinctive expressions of parochialism according to whether individuals were managing their own problems or problems involving others. Next, we report the outcomes and provide qualitative evidence according to in-group and out-group closed-mindedness or self-protection outcomes. Figure 1 reflects the coding process for the parochialism dimensions.

\section{INSERT FIGURE 1 ABOUT HERE}

\section{The Cognitive Dimensions of Closed-mindedness}

Several interviewees indicated that parochial managers refuse to consider new ideas. They distrusted outsiders or foreigners and relied instead on their own experience or advice from 
friends or relatives. Interviewees also reported that parochial managers were often contented with minimal standards and used temporary solutions to problems rather than seeking root causes or challenging the status quo for long-term solutions. We categorized those traits under the cognitive dimension of parochial closed-mindedness, consistent with arguments that closedminded people generally avoid exposure to belief-discrepant information, seek to reinforce their beliefs, and focus on the short-term interests of in-group circles (Hunt Jr \& Miller, 1968; Kruglanski, 2013). Easterners such as Chinese tend to solve problems according to practical experiences rather than scientific methods (Nisbett et al., 2001), because they feel that following the old ways is the only way to achieve security. The desire for predictability causes resistance to alternative opinions or inconsistent evidence and perpetuates closed-minded attitudes toward new information (Webster \& Kruglanski, 1994). As a result, communication can be excessively biased toward preexisting perspectives.

\section{The Behavioral Dimension of Self-Protection}

In discussing parochialism, interviewees mentioned the lack of initiative to communicate with culturally different others, the resistance to information disclosure, and the focus on facesaving, especially for coping with potential or actual threat and to avoid exposing deficiencies. We label this behavioral dimension as self-protection (Alicke \& Sedikides, 2009), a way to maximize positive experiences for responding to uncertainties and threats to self-interests (Chiu, Wan, Cheng, Kim, \& Yang, 2011; Sedikides, 2012). Self-protection focuses on saving face (House et al., 2004) to ensure positive self-views, but it may fail to bring optimal outcomes (Sedikides, 2012).

\section{The Relational Dimension of In-group Focused Social Relationship}


Recall that China's unique social structure causes the Chinese to favor in-groups tied by family, friendship, common traits, and common goals (Zhang et al., 2015). Less favorable treatment is afforded to out-group members lacking connections or common interests (Liu, Friedman, \& Hong, 2012).

In-group closed-mindedness reflects the parochial tendency to avoid unpleasant cognitive conflict (Hunt Jr, \& Miller, 1968) and to ensure that in-group circles remain harmonious (Zhang et al., 2015). Our data showed that when highly parochial individuals deal with in-group problems or challenges, their closed-mindedness cognition allows them to be content with minimal standards, to resist change, and blindly trust in-group members. For example, one HR manager for a foreign automotive company in China stated:

The parochial leader is stingy and static, not daring to accept challenges despite opportunities, easily contented with the status quo. (C7)

A Chinese manager summarized in-group closed-mindedness:

Parochial people think only of their personal needs and interests rather than important and meaningful questions. They are satisfied with their momentary positions and shortterm happiness. (C8)

Out-group closed-mindedness indicates that parochial individuals tend to avoid uncertainty by seeking quick solutions or rejecting different options when problems or challenges involve members outside their social circles (Kruglanski, 2013). The data show that out-group closedmindedness could motivate the pursuit of short-term gains, the search for shortcuts to solving problems, and distrust of out-group members. A Chinese manager stated:

Parochialist individuals are very concerned about their own interests. They wish to invest very little but expect great returns. They lack long-term vision and will avoid taking 
initiative to respond to negativity or adversity in the outside world. Instead of investing for the long-term, they cherish immediate benefits. (C7)

When parochial individuals deal with problems involving themselves or in-group members, they will use in-group self-protection to preserve their self-image or save face (Hepper, Sedikides, \& Cai, 2013; Liang, 1987). Interviewees indicated that parochial managers did not proactively communicate with their foreign partners when problems emerged. An American executive said:

I found out about a shipment delivery problem, but nobody told me until I asked. Same problem in the factory, they always try to hide problems and hope they will somehow go away. However, all I need is for someone to let me know as soon as possible so I can explain what is happening to my customers. (A2)

Parochial people tend to desire to maintain face through "face work" in front of others within the same social network, so they may make reckless, illogical, or irresponsible decisions just to maintain self-image (Hwang, 1987). An American attorney discussed his experience with Chinese firms who failed to use due diligence in acquisition bidding. He said, "I think part of it is the whole 'face' thing. It's like: let me showcase me here."

When parochial individuals interact with out-group members, they tend to use out-group self-protection to defend self-interest and maximize self-benefits in reaction to perceived potential threats, even remote possibilities of receiving unwanted news or information (Sedikides, 2012). An American manager explained that out-group self-protection can lead to various selfish behaviors such as unwillingness to share with out-group members, lack of social participation, and disregard for common laws: 
A lot of self-centered Chinese love nature and beautiful scenery and beautiful mountain vistas. Yet in areas such as Guilin they think nothing of throwing plastic sandwich wrappers on the ground. They don't even see it. (A1)

A Chinese manager explained that parochial individuals would even manufacture obstacles to sabotage other's performance to get ahead, ignoring impacts on others:

[A parochial person] thinks that if he/she cares about and help others, then others will outperform him/her. And others may be selected as outstanding employees instead of $\mathrm{him} / \mathrm{her}$. The Chinese traditional thinking is that if 10,000 people are poor, we can be poor together. But we don't want anyone else to be better off. (C5)

Figure 2 illustrates the conceptual dimensions and components. The three dimensions of closed-mindedness, self-protection, and in-group-focused relationships are interconnected, based on the empirical evidence found from our interviews. The relational dimension is particularly relevant to Chinese traditional thought that shapes interpersonal relationships, communication, and temporal considerations (Chen \& Miller, 2011) and interacts with the cognitive and behavioral dimensions.

INSERT FIGURE 2 ABOUT HERE

\section{PAROCHIALISM AND CHINESE FIRMS' GLOBALIZATION}

Researcher and practitioners are challenged to analyze the predicaments confronting Chinese firms as they enter global competition (Leung, 2014). We found that parochialism directly hinders globalization of Chinese firms in five key areas of organizational culture: 1) employee development, 2) communication, 3) customer orientation, 4) social responsibility, 5) strategic planning and innovation (Tsui, Wang, \& Xin, 2006). The first two facets relate to internal 
integration; the other three relate to external adaptation. The data were coded to represent parochialism effects in the context of globalization of Chinese firms (figure 3).

\section{INSERT FIGURE 3 ABOUT HERE}

\section{Employee Development}

Interviewees reported that parochialistic blind trust toward in-group members and distrust of outgroup members prevents companies from developing, engaging, and empowering employees. An HR manager from China commented:

Managers with parochial mindsets rarely delegate authority. They always want to concentrate power around themselves. Under such leaders, the deputies might have strong execution skills but often lack innovation. Parochial managers often worry about being replaced, so they avoid delegating work or developing subordinates. (C3) Chinese companies tend to feature patriarchal relationships in which bosses, usually men, play father roles in developing subordinates (Hofstede et al., 2010). However, Chinese society is categorized as a low-trust society in which citizens tend to distrust out-group members (Lee \& Dawes, 2005; Yao, Zhang, Brett, \& Murnighan, 2017). Managers tend to trust and collaborate with in-group members only to ensure safety and security for themselves (House et al., 2004; Redding, 1990). Because of out-group distrust, relational networks and family ties rather than applicant capability usually determine whether workers are hired or promoted (Chen et al., 2004; Wen, Lau, \& Lam, 2012). An American CEO, a business partner with Chinese manufacturers, shared that impression:

They don't know the worth of talented folks. You must pay them well or you won't get good people. Chinese companies can't get their head around the fact that they have to pay 
premium compensation, although that would make them more successful in the U.S. market. (A1)

Parochial managers innately distrust and are thus unwilling to empower employees (Humborstad, Humborstad, Whitfield, \& Perry, 2008; Zhang, Tsui, Song, Li, \& Jia, 2008). When mistakes happen, they tend to blame subordinates rather than take leadership responsibility. As a result, Chinese companies lack long-term investments in employee training, development, and mentoring (Hutchings, Zhu, Cooper, Zhang, \& Shao, 2009). An interviewee commented:

The Chinese boss doesn't want to spend money on employee training, thinking that employees might leave after training. (C5)

A director of a service partner of a Chinese manufacturer witnessed high turnover in a Chinese firm and commented:

Just because you're a Chinese company, you don't have to bring everybody from China. Every time I go over to the Chinese company, they have hired about 4 or 5 Americans, but the Americans don't stay because the company is still very Chinese. (A7)

The quotes show that parochialism leads to low trust, low employee empowerment, and low employee engagement. Those consequences could be exacerbated when a company goes global. Chinese companies operating overseas tend to send Chinese managers and to create a glass ceiling against non-home staff (Accenture, 2013). If the organizational culture is infiltrated with parochialism, it will be difficult to attract and retain global talents, making the company less cross-culturally adaptable or competitive in the global market (Feng, Liu, \& Friedman, 2015). Based on our analysis, we propose: 
Proposition 1: When highly parochial companies operate overseas, they are less likely to provide autonomy to foreign subsidiaries, to invest in human recourses, or to reward local employees, leading to high levels of local employee turnover.

\section{Communication}

Parochial managers and employees impede intra- and inter-organizational knowledge sharing and learning because their closed minds prevent active communication and collaboration. One interviewee said:

Parochialism means that a farmer should take care of his own "1.3 acres of land." As long as he has enough food first, he won't have internal worries and can then develop new things. It's the same for business managers. They must first take care of their own responsibilities and stabilize their people. The second step is to share their experience, information, and ideas. People must satisfy and stabilize themselves before they can share with others. (C6)

Managers and employees who are focused on meeting their own needs first may withhold critical information from decision-making processes ( $\mathrm{Ng}$, Lee, \& Cardona, 2012), believing that withholding information gives an advantage they can use to maintain their expert status (Liu, 2003; Ng et al., 2012). Foreign companies can encounter extreme difficulty in getting clear answers from their parochial Chinese partners. Chinese companies may avoid active communications with partners, especially when operations go wrong, such as late deliveries or quality issues (A1, A2). Even when questioned, companies may deny or make excuses while resisting further improvement (A1). Without active communications and transparency, Chinese companies and partners cannot achieve trust and commitment for long-term strategic 
relationships (Chen, 2004; Liu, Luo, \& Liu, 2009). The American CEO described an incidence he experienced with his Chinese suppliers:

So, they went ahead and substituted aluminum to use in one of our low-horsepower motors but they didn't tell anyone. They didn't provide us any data, nothing. It was a disaster for us. I had to recall all the motors once we discovered it, and we managed to save the relationships through the process. But our Chinese partners had a hard time understanding why it was important, why it was a big deal, and why our customers would care what's inside the motors as long as it runs. (A1)

Thus, passive communication styles would prevent Chinese companies from communicating effectively with global stakeholders and building brand images. Unwillingness to share, resistance to learning, limited transparency, and highly ambiguous communication styles could be a major concern for Chinese companies going abroad. Based on this analysis, we propose:

Proposition 2: When highly parochial companies operate overseas, they are less likely to communicate or demonstrate knowledge sharing and learning with international partners.

\section{Customer Orientation}

Parochialists tend to be content with minimal standards, in alignment with the mindset of achieving short-term gains and maximizing personal benefits. The American interviewee criticized his Chinese suppliers:

They are interested in short-term performance. Often the first batch of samples looks okay. Then the second shipment has deteriorated in quality. You have to micro-manage, spend a lot of time validating critical materials before they're processed and then again afterward. (A1) 
Chinese companies are known to substitute cheaper materials for qualified materials and to bypass required quality procedures to cut costs and increase profits quickly, thus sacrificing long-term relationships built on consistent service and quality (Midler, 2010). They are often content with minimum standards and find difficulty in implementing total quality management (TQM) practices for precise and consistent quality (Philipsen \& Littrell, 2011). Indeed, the phenomenon of quality fade, "the deliberate and secretive habit of widening profit margins through a reduction in the quality of materials" (Midler, 2007), is widespread among exported goods from Chinese companies.

Chinese companies also make reckless decisions without logical reasons or due diligence during acquisition bidding processes for overseas investments. They often offer the highest price just to outbid others, flaunt their wealth, or save face. Such mentality leads to overpriced or completely unnecessary acquisitions. For those reasons, an attorney from a local legal service company (A5) working on such matters mentioned that American sellers are now leery about high bids from Chinese companies.

Interviewees detailed incidents showing that Chinese companies often lack customer orientation. As a result, foreign partners may hold their Chinese partners at arms-length for years (Liu et al., 2009). Face-driven decisions, falsified information, and unethical marketing approaches can destroy foreign investments (Dietz, Orr, \& Xing, 2008; Firth, Rui, \& Wu, 2011; Lin, 2004). Chinese companies have been repeatedly charged with fraud for misleading shareholders in stock exchange markets (Rapoport, 2015). Based on this analysis, we propose:

Proposition 3: When highly parochial companies go abroad, they are less likely to show precise quality and consistency, less likely to collaborate with foreign partners, and more likely to demonstrate face-driven investment decisions without due diligence. 


\section{Social Responsibility}

Highly parochial Chinese companies are less interested in building social relationship with local communities. An interviewee criticized a large Chinese firm located in the United States for lacking community involvement:

The company has plenty of resources to support community activities, more resources than other companies. Somehow, I feel they don't see the importance; they don't know that our society expects community involvement. They seldom participate in community and business networking events, or seminars and workshops. (A2)

Highly parochial Chinese firms operating overseas may disregard common law and local legal and environmental requirements. The director of a service company working with Chinese firms on foreign investments reported that a Chinese business refused to honor zoning requirements when they built a factory in the United States:

They want to build it Chinese style, with factory dormitories for workers. (A8) Another interviewee summarized:

The legal aspect is one of the biggest issues. Any law firms that have legal experience with Chinese firms will tell you that what works in China might not necessarily work [in the U.S]. (A7)

Although companies should accept corporate social responsibility (CSR) as an ethical obligation and an opportunity to enhance their global competencies and images, parochial Chinese companies take few CSR initiatives (Cui, Liang, \& Lu, 2014; Graafland \& Zhang, 2014). Our interview data revealed that they are less interested in building long-term relationships with local communities through social participation, adherence to local legal requirements, and investment in CSR initiatives. Therefore, we propose: 
Proposition 4: Highly parochial companies operating overseas are less likely to engage in CSR and are more likely to overlook local legal and environmental requirements.

\section{Strategic Planning and Innovation}

The parochial elements of pursuing short-term gains, resisting changes, and searching for shortcuts also impede the strategic growth of Chinese companies. Interviewees provided their views of parochial leaders:

They have only limited vision and focus on their personal gains. They consider their own family or close acquaintances and ignore social progress or company development. (C6)

Although the literature has argued that Chinese leaders are long-term oriented (Hofstede et al., 2010), actually they are often driven by short-term results for quick profits and selfinterests rather than by the desire to develop core competencies or competitive advantages for long-term growth (Faure \& Fang, 2008; House et al., 2004). Even when they have plans, they are often distracted by opportunistic possibilities for quick returns, such as investment in real estate properties rather than $\mathrm{R} \& \mathrm{D}$ (Liu, 2013). In fact, foreign partners perceive the short-term orientation and the lack of strategic focus of their Chinese partners as a major problem (Faure \& Fang, 2008).

Chinese companies tend to have limited structures, rules, or practices for developing innovation. Many companies lack desire for breakthroughs or novel innovations through longterm investments; instead, they can use reverse engineering, sell products more cheaply, and make quick profits. Instead of investing in $R \& D$, many companies simply replicate successful business models and products as shortcuts for success. "Copycat" or counterfeiting businesses flourish amid the weak protection of intellectual property rights in China (Gerth, 2010). The CEO of an American company commented: 
A lot of Chinese companies become successful by making a product that is almost as good as anything else because they just copied it and sold it for $20 \%$ less. That's how they gain market share. Very few have invented really innovative new products to capture the market. (A1)

The director of sales and product development (A8) also talked about dealing with their manufactory located in China: "The engineers in China have a natural fear of being wrong. Therefore they have a copy mentality."

The "copycat" strategy helps establish initial financial foundations. But without original innovation, companies must constantly try to catch up with industry leaders and cannot sustain themselves as market players. China's lack of strategic planning and innovation culture will harm Chinese businesses in the long run. The "copycat" or fake culture greatly impairs their reputation. Foreign alliances are reluctant to share key technologies because of the lack of intellectual property protection. "Made-in-China" products are perceived as cheap and shoddy. Those perceptions will essentially prevent Chinese companies from advancing in the global value chain. As an interviewee concluded:

Few Chinese firms last more than one hundred years because they lack long-term vision and focus only on short-term benefits. Therefore, parochialism prevents sustainable development. (C3)

Therefore, we propose:

Proposition 5: Highly parochial companies are more likely to use "copycat" strategies for innovation and are less likely to have strategic long-term vision in overseas markets. In summary, under the influences of parochialism, Chinese companies often make shortterm decisions for quick returns but impair their long-term sustainability. They focus less on 
global talent development and are less likely to engage with their local employees and communities. Their foreign business partners may keep their relationships distant because Chinese companies lack transparency and open communication. Without focusing on the development of core competencies, parochial companies undermine innovative investments and quality standards and are often distracted by other business opportunities. Because they show

little interest in CSR, they earn negative impressions overseas. Such behaviors are counter to the global mindset and universal values, and thus hinder global adaptation.

\section{DISCUSSION}

\section{Prospects for a New Concept}

In this article, we explore the concept of parochialism and discuss its implications for the globalization of Chinese firms. By discussing parochialism as a dark side of Chinese culture, we by no means discount positive elements of Chinese culture and traditions. The three intellectual traditions of Buddhism, Taoism, and Confucianism contain ideas of balance, adaptation, and moral compass which connect individuals to fundamental moral principles, as suggested in the emerging idea of ambiculturalism (Chen, 2014). Revealing parochialism as a cognitive barrier preventing organizational learning, sharing, and innovation in globalization processes, we hope that we provide practical guidance for Chinese managers in their search for antidotes against engrained and habitual parochialistic thinking and behaviors. With the awareness and desire to overcome such cognitive barriers, Chinese managers and executives can take steps to cultivate active learning and self-reflection in intercultural contexts among generational, professional, regional, organizational, or national cultures. Active learning requires the absorption of new knowledge that opens minds and facilitates cooperative social interactions. Acquiring global mindsets and cosmopolitanism can encourage ambiculturalism that integrates the best and 
eliminates the worst of Western and Eastern cultures (Chen, 2014; Chen \& Miller, 2010). We hope our efforts to clarify the meaning and dimensions of parochialism make headways in moving toward such a progressive future.

\section{Implications for Organizational Research}

By clarifying the conceptual dimensions of parochialism and offering propositions in the context of globalization for Chinese firms, we make several contributions to organization research. First, our propose that the cultural mindset of parochialism resulting from long-standing political, economic, and cultural traditions (Leung, 2008) expands current literature and explains paradoxical behaviors of Chinese managers and firms in the global marketplace. Various cultural frameworks have explained Chinese organizational behaviors through values (Hofstede, 2001; Schwartz, 1999), norms (Gelfand et al., 2011; House et al., 2004; Liu, Friedman, \& Chi, 2005), social axioms (Leung \& Bond, 2004; Leung et al., 2002), and Chinese personality (Cheung, Cheung, Leung, Ward, \& Leong, 2003). However, researchers and practitioners are still puzzled about many behaviors observed in Chinese managers (Huang \& Bond, 2012). Parochialism complements cultural frameworks and addresses some paradoxes in Chinese organizations (Chen, 2002; Faure \& Fang, 2008). Chinese managers who are highly influenced by parochialism will make decisions that influence lower-level employees and business operations. Furthermore, subordinates with similar mindset may share collective cognition and actions that exacerbate poor collaboration with out-group partners.

Second, the extant literature attributes the poor performance of Chinese firms overseas to cultural differences, weak managerial skills, and inexperience, but the explanation is incomplete (Redding, 2014). Parochialism, rooted in China's ecological and sociocultural context (Tsui, 2012), offers an alternative explanation as a cognitive barrier which prevents Chinese companies 
from successful integration and advancement in the global value chain. Without awareness of the presence of such cultural mindsets, foreign partners can blindly accommodate such behaviors and long-term market egalitarianism will suffer. By defining the conceptual property of parochialism, we offer managerial implications for Chinese managers to recognize and detach from such cognitive barriers, especially during globalization processes. The understanding of parochialism and its implications on the global business society is timely and relevant for researchers to provide responsible and practical solutions to societal issues (Tsui, 2013).

Third, we show that the past societal environment continues to influence present mindsets. Although society has changed, environments experienced in childhood and early adolescence continue to affect the mindsets of many Chinese business leaders (Egri \& Ralston, 2004). Unfortunately, active business leaders from older generations are likely to reflect the parochial mindsets of the present. Social psychological studies on attitude change, such as (i.e., the PAST model, see Petty et al., 2006), explain why people hold to previous attitudes. Parochialism was developed in the past environment in China while remains through generations as a form of cultural mindset. The "past attitude" contrasts with the fast development of Chinese companies in the last four decades and creates the problems identified in the study. That is, when firms go global, their performance is damaged if they refuse to adapt to management practices and norms in the host environment.

Last, our proposed concept of parochialism is embedded in the Chinese context, but we also contribute to cross-cultural management research. Parochialism contains the key dimensions of closed-mindedness, self-protection behaviors, and in-group oriented relationships. Thus parochialism can occur outside China, but it is often confined by local institutions and social environments (Leung, 2012b). Parochialism could be more pervasive in some countries but less 
in others. It is more salient and widespread in China because of the historical, cultural, and institutional environment. Different institutional environments may have generated different selfconcepts, so that in-group and out-group divisions may be less distinct (Markus \& Kitayama, 1991). In addition, parochialism may be a stronger impediment for Chinese firms because of their scale and rapid growth rate (Shenkar, 2009). However, parochialism can be generalized to other emerging markets with long traditions or related to island mentality in the British or Japanese cultures (Bowell, 2011; Caron, 2014; Economist, 2014; Meadowcroft, 2011). Different levels of parochialism may occur in urban and rural areas not only in China but also in other countries. Parochialism could also surface in developed societies as one of the consequences of globalization (Hong \& Cheon, 2017). Understanding parochialism across cultures becomes particularly relevant and urgent today with the growing social movement toward "right-wing authoritarianism" and anti-globalism (Altemeyer, 1981; Jost et al., 2007). Future interdisciplinary research can study how parochialism might relate to liberal and conservative ideologies.

\section{Boundary Conditions of Parochialism}

Parochialism in Chinese firms may make it more difficult to overcome the liability of foreignness and gain legitimacy in global markets (DiMaggio \& Powell, 1983; Scott, 1995; Zaheer, 1995), but other important contextual factors can reduce or amplify the impact of parochialism such as institutional environments (Scott, 1995) and cultural distance (Morosini, Shane, \& Singh, 1998; Tihanyi, Griffith, \& Russell, 2005).

Parochialism is subject to various individual factors. Many Chinese executives have global mindsets and have competently and successfully led multinational companies. For instance, Zhang Ruimin of Haier is an open-minded, eager-to-learn, cosmopolitan leader who 
has achieved competitive success in the global market (Li, 2013). Second, personal experience can open minds and counter parochialism. In the process of globalization and cross-border merger and acquisitions, Chinese executives have become humble and learning-oriented. They now empower expats and local employees, even provide stakeholder positions. Such transformations have allowed Chinese companies to become star acquirers in the sixth global merger wave (McCarthy, Dolfsma, \& Weitzel, 2016). At the societal level, millions of workers migrate from rural to urban regions and bring home new knowledge and information. Thus, urbanization and increased cosmopolitan exposure may raise awareness, self-reflection, and potential correction of parochialism. Indeed, people learn to collaborate and trust others when they have positive experiences with strangers (Yao et al., 2017). Furthermore, Chinese youth have more freedom to go abroad, learn new ideas, and pursue independence. Modern social media also brings extensive information and increased worldwide communication. We are hopeful that the new generations of Chinese business leaders will gradually reduce parochialism within and outside their organizations, with increasing impacts on the community and engagement with society in general.

\section{Future Empirical Research on Parochialism}

In this paper, we present an empirical effort to explore the conceptual property and consequences of parochialism in the context of Chinese firms' globalization. Although our qualitative interview data provide first-hand evidence of the meaning and effects of parochialism, more work is needed to deepen and broaden the empirical research on parochialism.

First, based on the cognitive, behavioral, and relational dimensions, future research can develop scales to quantitatively measure parochialism with larger sample sizes. Empirical evidence can provide insights to validate the precise conceptual properties and refine the 
dimensions. Second, future empirical studies could use case studies and surveys from multiple sources to identify the antecedents of parochialism at multiple levels of analysis such as individual, team, organizational, industry, country, or geographic levels. Because parochialism is a widespread phenomenon among Chinese, we might derive interesting findings for management and organizations by using a broader sample involving the general population to investigate how parochialism manifests at collective levels. For example, we might find higher levels of parochialism among older business leaders who are less educated or have had shorter exposure to urban working environments. Furthermore, urban and rural regions could show geographic-level differences. Higher levels of parochialism might be found in business leaders operating in the inner provinces or in poorly developed regions with relatively tight norms (Gelfand et al., 2011) .

Third, drawing from the extant sociology and psychology literature, we propose that China's parochialism is influenced by its unique institutional, economic, and cultural factors. Although parochialism is a salient Chinese concept, a cross-cultural sample including participants in other Confucian countries or emerging markets could also offer opportunities to study the broader external validity and influence of parochialism in other cultural contexts. Future research can test the boundary conditions and relationship between parochialism and specific cultural profiles such as the United States, United Kingdom, India, and Turkey. Parochialism might also explain why some foreign companies fail in China. Further study can address how parochialism may impact companies that originate outside China. In addition, longitudinal studies would aid in investigating parochialism as it interacts with evolvement, acquisition, activation processes, as well as the antecedents, consequences, moderators, and mediators at individual, organization, and institutional/societal levels. For example, at the organizational level, future research might study cases in which a company such as Huawei 
transformed from a parochialist to a global mindset. At the regional level, archival data of foreign companies in the area can be used to examine whether interactions with foreign counterparts increase or transform parochialism. In advanced economies, an uneven globalization may result in the rise of parochialism. The linkage and transformation between globalism and parochialism can be another area of promising research. 


\section{REFERENCES}

Accenture 2013. The human to touch behind Asia Inc.'s global push.

Alicke, M. D. \& Sedikides, C. 2009. Self-enhancement and self-protection: What they are and what they do. European Review of Social Psychology, 20(1): 1-48.

Altemeyer, B. 1981. Right-wing Authoritarianism: University of Manitoba Press.

Barr, P. S., Stimpert, J. L. \& Huff, A. S. 1992. Cognitive change, strategic action, and organizational renewal. Strategic management journal, 13(S1): 15-36.

Bowell, A. 2011. Returning to Britain's island mentality. The Huffington Post.

Caron, J. The Japan Times. 2014. Conservatives’ insular mindset doesn’t fit today's global reality.

Charmaz, K. 2006. Constructing Grounding Theory - A Practical Guide through Qualitative Analysis: Sage Publications, Inc.

Chen, C. C., Chen, Y.-R. \& Xin, K. 2004. Guanxi Practices and Trust in Management: A Procedural Justice Perspective. Organization Science, 15(2): 200-209.

Chen, C. C., Chen, X. P. \& Huang, S. S. 2013. Guanxi and Social Network Research: Review and Future Directions. . Management and Organization Review, 9(1): 167-207.

Chen, C. C., Friedman, R. \& Mcallister, D. J. 2017. Seeing and studying China: Leveraging phenomenon-based research in China for theory advancement. Organizational Behavior and Human Decision Processes, 143: 1-7.

Chen, M.-J. 2001. Inside Chinese Business: A Guide for Managers Worldwide, Boston.

Chen, M.-J. 2002. Transcending paradox: The Chinese "middle way" perspective. Asia Pacific Journal of Management, 19: 179-199.

Chen, M.-J. \& Miller, D. 2010. West meets East: Toward an ambicultural approach to management. The Academy of Management Perspectives, 24(4): 17-24.

Chen, M.-J. \& Miller, D. 2011. The relational perspective as a business mindset: Managerial implications for East and West. The Academy of Management Perspectives, 25(3): 6-18.

Chen, M.-J. 2014. Becoming Ambicultural: A Personal Quest, and Aspiration for Organizations. Academy of Management Review, 39(2): 119-137.

Chen, X.-P., And Chao C. Chen 2004. On the intricacies of the Chinese guanxi: A process model of guanxi development. Asia Pacific Journal of Management, 21(3): 305-324. 
Cheung, F. M., Leung, K., Fan, R., Song, W.-Z., Zhang, J.-X. \& Zhang, J. P. 1996. Development of the Chinese Personality Assessment Inventory (CPAI). Journal of Cross-Cultural Psychology, 27: 181-199.

Cheung, F. M., Cheung, S. F., Leung, K., Ward, C. \& Leong, F. 2003. The English version of the Chinese personality assessment inventory. Journal of Cross-Cultural Psychology, 34(4): 433-452.

Child, J. \& Marinova, S. 2014. The Role of Contextual Combinations in the Globalization of Chinese Firms. Management and Organization Review, 10(3): 347-371.

Chiu, C.-Y., Wan, C., Cheng, S. Y., Kim, Y.-H. \& Yang, Y. J. 2011. Cultural perspectives on self-enhancement and self-protection. In Alicke, M. D. \& Sedikides, C. (Eds.) Handbook of Self-Enhancement and Self-Protection: 425-451. The Guilford Press.

Cho, J. Y. \& Lee, E.-H. 2014. Reducing confusion about grounded theory and qualitative content analysis: Similarities and differences. The Qualitative Report, 19(32): 1.

Corley, K. G. \& Gioia, D. A. 2004. Identity ambiguity and change in the wake of a corporate spin-off. Administrative Science Quarterly, 49(2): 173-208.

Cui, Z., Liang, X. \& Lu, X. 2014. Prize or Price? Corporate Social Responsibility Commitment and Sales Performance in the Chinese Private Sector. Management and Organization Review, 11(1): 25-44.

Deng, X. \& Li, Q. 2005. 民营中小企业成长的瓶颈一一兼对小农意识的批判 (The bottleneck of the growth of private small and medium - sized enterprises - Criticism on Xiao Nong Yi Shi). Technoeconomics \& Management Research, 6: 50-51.

Dietz, M. C., Orr, G. \& Xing, J. 2008. How Chinese companies can succeed abroad. McKinsey quarterly, 3.

Dimaggio, P. J. \& Powell, W. W. 1983. The iron cage revisited: Institutional isomorphism and collective rationality in organizational fields. American Sociological Review, 48: 147160 .

Economist. The Economist. 2014. Island mentality: Bad schools and low aspirations used to be inner-city problems. Not any more.

Egri, C. P. \& Ralston, D. A. 2004. Generation cohorts and personal values: A comparison of China and the United States. Organization science, 15(2): 210-220.

Eisenhardt, K. M. 1989. Building theories from case study research Academy of Management Review, 14(4): 532-550.

Fairbank, J. K. 1979. The United States and China: Harvard University Press. 
Farh, J.-L., Earley, P. C. \& Lin, S.-C. 1997. Impetus for action: A cultural analysis of justice and organizational citizenship behavior in Chinese society. Admistrative Science Quarterly, 42(3): 421-444.

Faure, G. O. \& Fang, T. 2008. Changing Chinese values: Keeping up with paradoxes. International Business Review, 17(2): 194-207.

Fei, X., Hamilton, G. G. \& Wang, Z. 1992. From the soil, the foundations of Chinese society: a translation of Fei Xiaotong's Xiangtu Zhongguo, with an introduction and epilogue: University of California Press.

Feng, J. B., Liu, L. A. \& Friedman, R. 2015. Cross-Cultural adaptation to functional fitness: Evidence from Chinese Firms Operating in the United States. Academy of Management 11373.

Firth, M., Rui, O. M. \& Wu, W. 2011. Cooking the books: Recipes and costs of falsified financial statements in China. Journal of Corporate Finance, 17(2): 371-390.

Fischer, R. 2012. Locating Chinese work behavior in a global perspective. In Huang, X. \& Bond, M. H. (Eds.) The Handbook of Chinese Organizational Behavior: Integrating Theory, Research, and Practice: 48-62. Edward Elgar Publishing Limited.

Gelfand, M. J., Raver, J. L., Nishii, L., Leslie, L. M., Lun, J. \& Lim, B. C. 2011. Differences between tight and loose cultures: a 33-nation study. Science, 332: 1100-1104.

Gerth, K. 2010. As China Goes, so Goes the World: How Chinese Consumers are Transforming Everything, New York: Hill and Wang.

Gioia, D. A., Corley, K. G. \& Hamilton, A. L. 2013. Seeking qualitative rigor in inductive research: Notes on the Gioia methodology. Organizational Research Methods, 16(15): $15-31$.

Graafland, J. \& Zhang, L. 2014. Corporate social responsibility in China: implementation and challenges. Business Ethics: A European Review, 23(1): 34-49.

Hepper, E. G., Sedikides, C. \& Cai, H. 2013. Self-enhancement and self-protection strategies in China: Cultural expressions of a fundamental human motive. Journal of Cross-Cultural Psychology, 44(1).

Ho, D. Y.-F. 1976. On the concept of Face. American Journal of Sociology, 81(4): 867-884.

Hofstede, G. 2001. Culture's consequences: Comparing values, behaviors, institutions, and organizations across nations: Thousand Oaks, California: Sage Publications, Inc.

Hofstede, G., Hofstede, G. J. \& Minkov, M. 2010. Cultures and organizations: Software of the mind: London: McGraw-Hill. 
Hong, Y.-Y. \& Cheon, B. K. 2017. How does culture matter in the face of globalization? Perspectives on Psychological Science, 12(5): 810-823.

House, R. J., Hanges, P. J., Javidan, M., Dorfman, P. W. \& Gupta, V. 2004. Culture, Leadership, and Organizations: The GLOBE Study of 62 Societies: Thousand Oaks, CA: Sage.

Huang, X. \& Bond, M. H. 2012. Why we need this edited book now! In Huang, X. \& Bond, M. H. (Eds.) Handbook of Chinese organizational behavior: Integrating theory, research and practice: $3-10$. Edward Elgar Publishing.

Huff, A. S. 1990. Mapping strategic thought: John Wiley \& Sons.

Huff, L. \& Kelley, L. 2003. Levels of organizational trust in individualist versus collectivist societies: A seven-nation study. Organization Science, 14(1): 81-90.

Humborstad, S. I. W., Humborstad, B., Whitfield, R. \& Perry, C. 2008. Implementation of empowerment in Chinese high power-distance organizations. The International Journal of Human Resource Management, 19(7): 1349-1364.

Hunt Jr, M. F. \& Miller, G. R. 1968. Open-and closed-mindedness, belief-discrepant communication behvior, and tolerance for cognitive inconsistency. Journal of Personality and Social Psychology, 8(1): 35.

Hutchings, K., Zhu, C. J., Cooper, B. K., Zhang, Y. \& Shao, S. 2009. Perceptions of the effectiveness of training and development of 'grey-collar'workers in the People's Republic of China. Human Resource Development International, 12(3): 279-296.

Hwang, K.-K. 1987. Face and Favor: The Chinese Power Game. American Journal of Sociology, 92(4): 944-974.

Jost, J. T., Glaser, J., Kruglanski, A. W. \& Sulloway, F. J. 2003. Political conservatism as motivated social cognition. Psychological Bulletin, 129(3): 339-375.

Jost, J. T., Napier, J. L., Thorisdottir, H., Gosling, S. D., Palfai, T. P. \& Ostafin, B. 2007. Are needs to manage uncertainty and threat associated with political conservatism or ideological extremity? Personality and Social Psychology Bulletin, 33(7): 989-1007.

Kruglanski, A. W. 2013. The Psychology of Closed Mindedness: Psychology Press.

Lalwani, A. K., Shavitt, S. \& Johnson, T. 2006. What is the relation between cultural orientation and socially desirable responding. Journal of Personality and Social pPsychology, 90(1): 165 .

Lee, D. Y. \& Dawes, P. L. 2005. Guanxi, trust, and long-term orientation in Chinese business markets. Journal of international marketing, 13(2): 28-56. 
Leung, K., Bond, M. H., Carrasquel, S. R. D., Muñoz, C., Hernández, M., Murakami, F., Yamaguchi, S., Bierbrauer, G. \& Singelis, T. M. 2002. Social axioms: The search for universal dimensions of general beliefs about how the world functions. Journal of CrossCultural Psychology, 33(3): 286-302.

Leung, K. \& Bond, M. H. 2004. Social axioms: A model for social beliefs in multicultural perspective. Advances in Experimental Social Psychology, 36: 119-197.

Leung, K. 2008. Chinese culture, modernization, and international business. International Business Review, 17(2): 184-187.

Leung, K. 2012a. Indigenous Chinese management research: Like it or not, we need it. Management and Organization Review, 8(1): 1-5.

Leung, K. 2012b. Theorizing about Chinese organizational behavior: the role of cultural and social forces. In Huang, X. \& Bond, M. H. (Eds.) Handbook of Chinese Organizational Behavior: Integrating Theory, Research and Practice Edward Elgar Publishing.

Leung, K. 2014. Globalization of Chinese Firms: What Happens to Culture. Management and Organization Review, 10(3): 391-397.

Levy, O., Beechler, S., Taylor, S. \& Boyacigiller., N. A. 2007. What we talk about when we talk about 'global mindset': Managerial cognition in multinational corporations. Journal of International Business Studies, 38(2): 231-258.

Li, P. 2013. Speech by Ruimin Zhang, CEO of Haier, at AOM. International Association for Chinese Management Research, Quarterly Newsletter, 9(3): 9-10.

Li, P. P., Leung, K., Chen, C. C. \& Luo, J. D. 2012. Indigenous research on Chinese management: What and how. Management and Organization Review 8, no. 1 (2012): 7 24., 8(1): 7-24.

Liang, S. M. 1987. 中国文化要义（The essence of Chinese culture）, Hong Kong: Joint Publishing (HK) Co., Ltd

Lin, T. W. 2004. Corporate governance in China: Recent developments, key problems and solutions. Journal of Accounting and Corporate Governance 1 (2004). 1.

Liu, D. 2013. A 股的 “异化” : 条条大路通地产 ("Alienation" of A share market: all the way through real estate ). China Economic Weekly, 23: 32-36.

Liu, L. A., Friedman, R. A. \& Chi, S. C. 2005. Ren Qing'versus the 'Big Five': the role of culturally sensitive measures of individual difference in distributive negotiations. Management and Organization Review, 1(2): 225-247. 
Liu, L. A., Friedman, R., Barry, B., Gelfand, M. J. \& Zhang, Z.-X. 2012. The dynamics of consensus building in intracultural and intercultural negotiations. Administrative Science Quarterly, 57(2): 269-304.

Liu, W., Friedman, R. \& Hong, Y.-Y. 2012. Culture and accountability in negotiation: Recognizing the importance of in-group relations. Organizational Behavior and Human Decision Processes, 117(1): 221-234.

Liu, X. 2003. The conflict between outside "airborne" managers and original management team and its influence on corporate effectiveness. Management World, 6: 105-13.

Liu, Y. 1996. 小农意识初探 （上） (The investigation of Xiao Nong Yi Shi -I ). 社会科学论坛 , 6:31-34.

Liu, Y. 1997a. 小农意识初探（下） (The investigation of Xiao Nong Yi Shi - III ). 社会科学论 坛, $2: 27-30$.

Liu, Y. 1997b. 小农意识初探（中） (The investigation of Xiao Nong Yi Shi -II ). 社会科学论 坛, $1: 36-38$.

Liu, Y., Luo, Y. \& Liu, T. 2009. Governing buyer-supplier relationships through transactional and relational mechanisms: Evidence from China. Journal of Operations Management, 27(4): 294-309.

Markus, H. R. \& Kitayama, S. 1991. Culture and the self: Implications for cognition, emotion, and motivation. Psychological review, 98(2): 224.

Mccarthy, K. J., Dolfsma, W. \& Weitzel, U. 2016. The first global merger wave and the enigma of Chinese performance. Management and Organization Review, 12(2): 221-248.

Meadowcroft, M. 2011. The danger of our island mentality. The Guardian.

Midler, P. 2007. 'Quality fade': China's great business challenge. Knowlege Wharton.

Midler, P. 2010. Poorly made in China: An insider's account of the China production game: John Wiley \& Son.

Miles, M. B. \& Huberman, A. M. 1994. Qualitative Data Analysis: An Expanded Sourcebook: Sage Publications, Incorporated.

Molinsky, A. L. 2013. The psychological processes of cultural retooling. Academy of Management Journal, 56(3): 683-710.

Morosini, P., Shane, S. \& Singh, H. 1998. National cultural distance and cross-border acquisition performance. Journal of International Business Studies 137-158. 
Myers, M. D. 2011. Qualitative Research in Business \& Management: Sage Publications, Inc.

Needham, J. 1954. Science and Civilisation in China: Cambridge University Press.

Ng, I., Lee, Y.-T. \& Cardona, P. 2012. Building teams in Chinese organizations. In Huang, X. \& Bond, M. H. (Eds.) Handbook of Chinese Organizational Behavior: Integrating Theory, Research and Practice Edward Elgar Publishing.

Nisbett, R. 2004. The geography of thought: How Asians and Westerners think differently... and why. SimonandSchuster. com.

Nisbett, R. E., Peng, K., Choi, I. \& Norenzayan, A. 2001. Culture and systems of thought: Holistic versus analytic cognition. Psychological Review, 108(2): 291-310.

Orlikowski, W. J. 2000. Using technology and constituting structures: A practice lens for studying technology in organizations. Organization Science, 11(4): 404-428.

Pan, Y., Rowney, J. A. \& Peterson, M. F. 2012. The structure of Chinese cultural traditions: An empirical study of business employees in China. Management and Organization Review, 8(1): 77-95.

Petty, R. E., Tormala, Z. L., Brinol, P. \& Jarvis, W. B. G. 2006. Implicit ambivalence from attitude change: an exploration of the PAST model. Journal of Personality and Social Psychology, 90(1): 21.

Philipsen, S. \& Littrell, R. F. 2011. Manufacturing Quality and Cultural Values in China. Asia Pacific Journal of Business and Management, 2(2): 26-44.

Rapoport, M. 2015. New York Global Group Chief Charged With Securities Fraud. The Wall Street Journal.

Redding, G. 1990. The Spirit of Chinese Capitalism: Walter de Gruyter.

Redding, G. 2014. The Unexamined Differences in Dreams: Chinese Firms' Globalization and Interface Challenges. Management and Organization Review, 10(3): 399-404.

Redding, G. 2016. The Needham question today. Management and Organization Review, 12(1): 25-34.

Rickert, E. J. 1998. Authoritarianism and economic threat: Implications for political behavior. Political Psychology 19(4): 707-720.

Schwartz, S. H. 1999. A theory of cultural values and some implications for work. Applied Psychology: An International Review, 48(4): 23-47.

Scott, W. R. 1995. Institutions and Organizations: Thousand oaks, CA: Sage.

Sedikides, C. 2012. Self-Protection. Handbook of self and identity: 327-353. 
Shenkar, O. 2009. Becoming multinational: challenges for Chinese firms. Journal of Chinese Economic and Foreign Trade Studies, 2(3): 149-162.

Song, F., Cadsby, C. B. \& Bi, Y. 2012. Trust, reciprocity, and guanxi in China: An experimental investigation. Management and Organization Review, 8(2): 397-421.

Strauss, A. \& Corbin, J. 1998. Basics of Qualitative Research: Techniques and Procedures for Developing Grounded Theory: Sagae.

Sun, L. 2004. 中国文化的深层结构(The deep structure of Chinese culture): Guilin Guangxi: Normal University Press.

Tihanyi, L., Griffith, D. A. \& Russell, C. J. 2005. The effect of cultural distance on entry mode choice, international diversification, and MNE performance: A meta-analysis. Journal of International Business Studies, 36(3): 270-283.

Triandis, H. C. 1995. Individualism \& collectivism: Westview Press.

Tsui, A. S. 2006. Contextualization in Chinese management research. Management and Organization Review, 2(1): 1-13.

Tsui, A. S., Wang, H. \& Xin, K. R. 2006. Organizational culture in China: An analysis of culture dimensions and culture types. Management and Organization Review, 2(3): 345-376.

Tsui, A. S. 2012. Contextualizing research in a modernizing China. In Huang, X. \& Bond, M. H. (Eds.) The Handbook of Chinese Organizational Behavior: Integrating Theory, Research, and Practice: 13-28. Edward Elgar Publishing Limited.

Tsui, A. S. 2013. The spirit of science and socially responsible scholarship. Management and Organization Review, 9(3): 375-394.

Webster, D. M. \& Kruglanski, A. W. 1994. Individual differences in need for cognitive closure. Journal of Personality and Social Psychology, 67(6): 1049.

Wen, S. S., Lau, D. C.-S. \& Lam, L. W. 2012. Enhancing trust in Chinese organizations. In Huang, X. \& Bond, M. H. (Eds.) The Handbook of Chinese Organizational Behavior: Integrating Theory, Research, and Practice: 289-306. Edward Elgar Publishing Limited.

Wu, X. 2013. 大败局 (Big losing battle): Zhe Jiang University Press.

Xin, K. K. \& Pearce, J. L. 1996. Guanxi: Connections as substitutes for formal institutional support. Academy of management journal, 39(6): 1641-1658.

Yao, J., Zhang, Z.-X., Brett, J. \& Murnighan, J. K. 2017. Understanding the trust deficit in China: Mapping positive experience and trust in strangers. Organizational Behavior and Human Decision Processes, 143: 85-97. 
Yuan, Y. 2000. 小农意识与中国现代化 (Xiao nong yi shi and Chinese modernization): 武漢 出版社.

Yuan, Y. 2012. 毛泽东改造小农意识的思想叙论(The discussion of reforming peasant mentality by Mao Zedong). China Academic Journal Electronic Publishing House, 1: $42-22$.

Zaheer, S. 1995. Overcoming the liability of foreignness. Academy of Management Journal, 38(2): 341-363.

Zhang, A. Y., Tsui, A. S., Song, L. J., Li, C. \& Jia, L. 2008. How do I trust thee? The employee - organization relationship, supervisory support, and middle manager trust in the organization. Human Resource Management, 47(1): 111-132.

Zhang, J.-D., Liu, L. A. \& Liu, W. 2015. Trust and deception in negotiation: Culturally divergent effects. Management and Organization Review, 11(1): 123-144.

Zhang, Z.-X., Chen, C. C., Liu, L. A. \& Liu, X.-F. 2008. Chinese traditions and Western theories: Influences on business leaders in China. In Chen, C. C. \& Lee, Y. T. (Eds.) Leadership and Management in China: Philosophies, Theories, and Practices: 239271. London: Cambridge University Press. 
Table 1 Summary of Interviewees

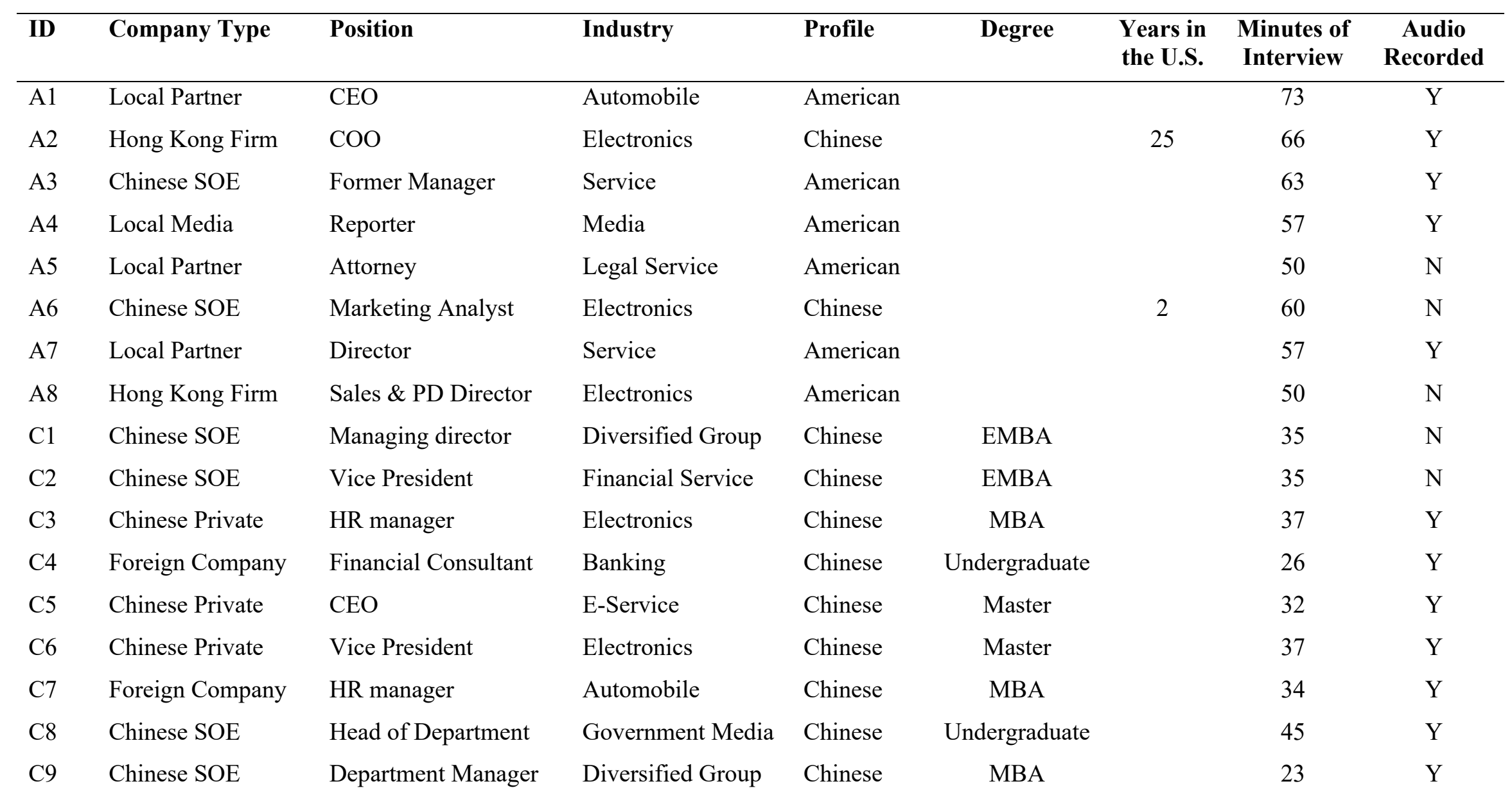




\section{Table 2 - Quotes of definition of Parochialism (Xiao Nong Yi Shi) By Interviewees}

\begin{tabular}{|c|c|c|}
\hline Interviewee & Chinese & English \\
\hline $\mathbf{C 3}$ & $\begin{array}{l}\text { 如果有人说, 你小农意识很重就说明你这个人没有 } \\
\text { 什么大出息, 没在大智慧, 没有大的格局, 目光短 } \\
\text { 浅。 }\end{array}$ & $\begin{array}{l}\text { If someone says that you are very parochial (xiao nong yi } \\
\text { shi), it means that you have no potential, no big wisdom, } \\
\text { no vision, and short-sighted. }\end{array}$ \\
\hline $\mathrm{C4}$ & $\begin{array}{l}\text { 小农意识的人，在思维上是受限的，它源自于农 } \\
\text { 民，他们在创新，突破的思维上是局限的。这样的 } \\
\text { 人不太愿意接受外来的信息，或者接受了也不能完 } \\
\text { 全地消化和吸收;或者只顾自己现有自己的利益，不 } \\
\text { 会考虑别人的感受和利益。 }\end{array}$ & $\begin{array}{l}\text { People with parochialism have limited thinking. It is } \\
\text { originated from peasants, who have limited innovation } \\
\text { and breakthrough. Such people are less willing to accept } \\
\text { new information or cannot completely digest and absorb } \\
\text { new information; they care only their own existing } \\
\text { interests and will not consider other people's feelings and } \\
\text { interests. }\end{array}$ \\
\hline C6 & $\begin{array}{l}\text { 安于现状, 更在乎眼前利益, 在行为举止上也有些 } \\
\text { 短视, 个人形象, 仪表也不是很好, 容易跟农村联 } \\
\text { 系在一起。 }\end{array}$ & $\begin{array}{l}\text { [They] remain the status quo, more concerned about the } \\
\text { immediate interests, and their behaviors are also } \\
\text { somewhat short-sighted. Their personal images and } \\
\text { appearances are not very good and can be easily } \\
\text { associated to the rural areas. }\end{array}$ \\
\hline $\mathrm{C5}$ & $\begin{array}{l}\text { 我觉得小农意识是中国传统的封建社会遗留下来的 } \\
\text { 习惯或意识吧, 可能是因为封建时代流动性也比较 } \\
\text { 局限, 再加上自给自足的经济体, 就导致了作为一 } \\
\text { 个独立自主的一个小的经济体, 他[们]可能在协作 } \\
\text { 上或者就管好自己的一亩三分地就可以了。他们可 } \\
\text { 能对于协作, 对于大局观都会比较的局限吧。 }\end{array}$ & $\begin{array}{l}\text { I think that parochialism is the legacy or consciousness } \\
\text { of traditional Chinese feudal society. It is probably } \\
\text { because of the limitations of the feudal era, coupled with } \\
\text { the self-sufficient economy, which led to the independent } \\
\text { small economy. They may only focus on the } \\
\text { collaboration and management within their own } 1.3 \text { acres } \\
\text { of land. They may be limited for collaboration or } \\
\text { thinking big pictures. }\end{array}$ \\
\hline
\end{tabular}




\begin{tabular}{|c|c|c|}
\hline C7 & $\begin{array}{l}\text { 小农意识的人整体上不够太开放, 不太愿意接受新 } \\
\text { 的思维, 方法, 管理理念, 局限于自己所在的圈子 } \\
\text { 里。如果相比来自城市与农村的同事, 直观的感觉 } \\
\text { 是农村人不是那么时尚, 不是那么开放。他们有他 } \\
\text { 们人群的特点, 可能比较善良, 纯朴, 但接受新生 } \\
\text { 事物的能力比较差, 对眼前或小的利益会看重的比 } \\
\text { 较重。 }\end{array}$ & $\begin{array}{l}\text { Overall, people with parochialism are not too open, not } \\
\text { willing to accept the new thoughts, methods, and } \\
\text { management ideas. They are confined to their own } \\
\text { circles. } \\
\text { If you compare you colleagues coming from to the urban } \\
\text { and rural areas, your intuitive feeling is that rural people } \\
\text { are not so fashionable, not so open. They have their own } \\
\text { characteristics: they may be more kind and simple, but } \\
\text { their ability to accept new ideas is relatively poor. They } \\
\text { also value more the immediate but small interests. }\end{array}$ \\
\hline C8 & $\begin{array}{l}\text { 从传统意义上讲，小农意识就是原始的，农村的， } \\
\text { 相对落后的，思想比较狭险的，目光比较短浅的想 } \\
\text { 法或一些行为或决策。 }\end{array}$ & $\begin{array}{l}\text { In the traditional sense, parochialism is original, rural, } \\
\text { relatively backward, narrow-minded, short-sighted } \\
\text { behaviors or decision-making. }\end{array}$ \\
\hline C9 & $\begin{array}{l}\text { 眼界不够开阔, 比较局限, 狭隘, 更多考虑自我的 } \\
\text { 东西, 很少考虑宏观方面的东西。小农意识大部分 } \\
\text { 应该是农村走出来的人带有的特有的农村烙下的痕 } \\
\text { 迹吧。 }\end{array}$ & $\begin{array}{l}\text { Parochial person has no vision, is more limited and } \\
\text { narrow-minded; They more consider for themselves, } \\
\text { rarely consider the macro aspects of issues. Parochialism } \\
\text { should trace back to the unique characters from people } \\
\text { who came out of the countryside. }\end{array}$ \\
\hline
\end{tabular}




\section{Figure 1 Exemplary Coding Process of Parochialism}

$1^{\text {st }}$ order themes

Lack of quality precision and consistency

Low trust and empowerment toward employees

Remain status quo

\section{Passive communication reduced transparency}

Limited trust and collaboration with foreign partners

Indulgence in face-driven risk taking without due

diligence

guanxi-based hiring and promotion practices

Limited investment on employee development

Lack of commitment to corporate social responsibility

Lack of strategic vision

Lack of innovation

Copy or counterfeit

\section{Limited sharing and learning}

Ambiguous communication caused misinterpretation

Falsified information

Overlook local legal and environmental requirements

Less interested in building relationships with local

communities $2^{\text {nd }}$ order categories

Content with minimal standards

Blinded trust towards in-group

Resistant to change

Passive communication

Reckless decision-making

Search for shortcuts

Out-group distrust

Maximize self-benefits

Unwilling to share

Lack of social participation

Disregard common laws
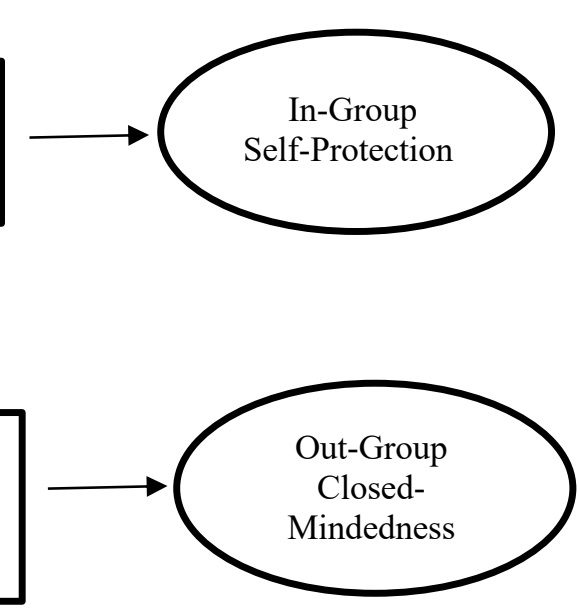

Aggregate dimensions
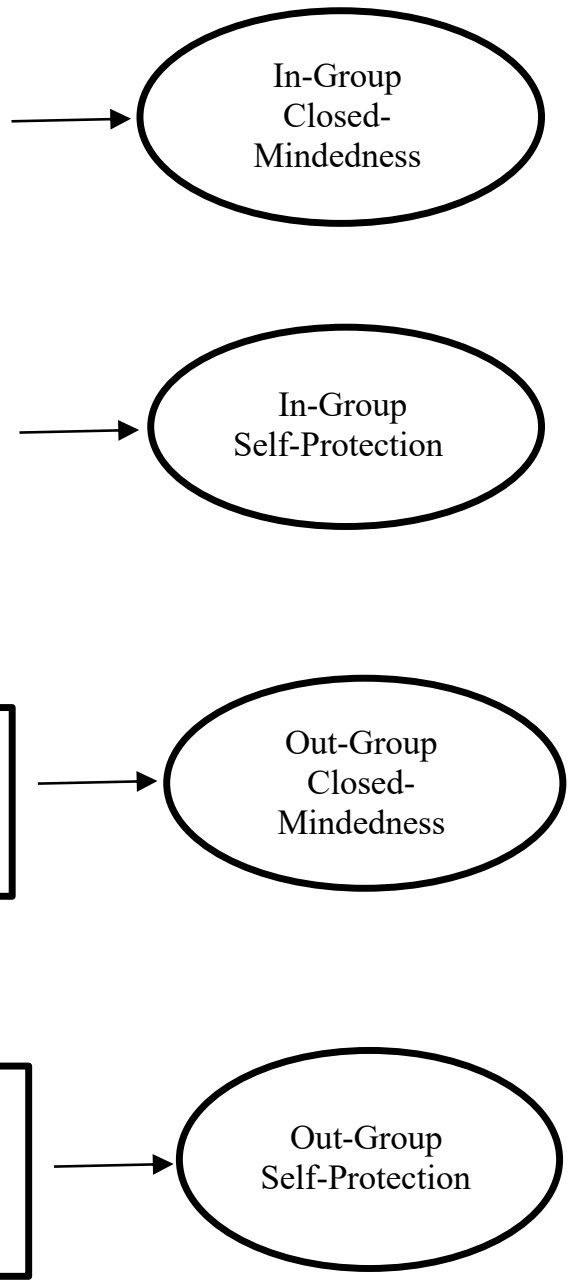
Figure 2 The Conceptual Dimensions and Manifestations of Parochialism in China

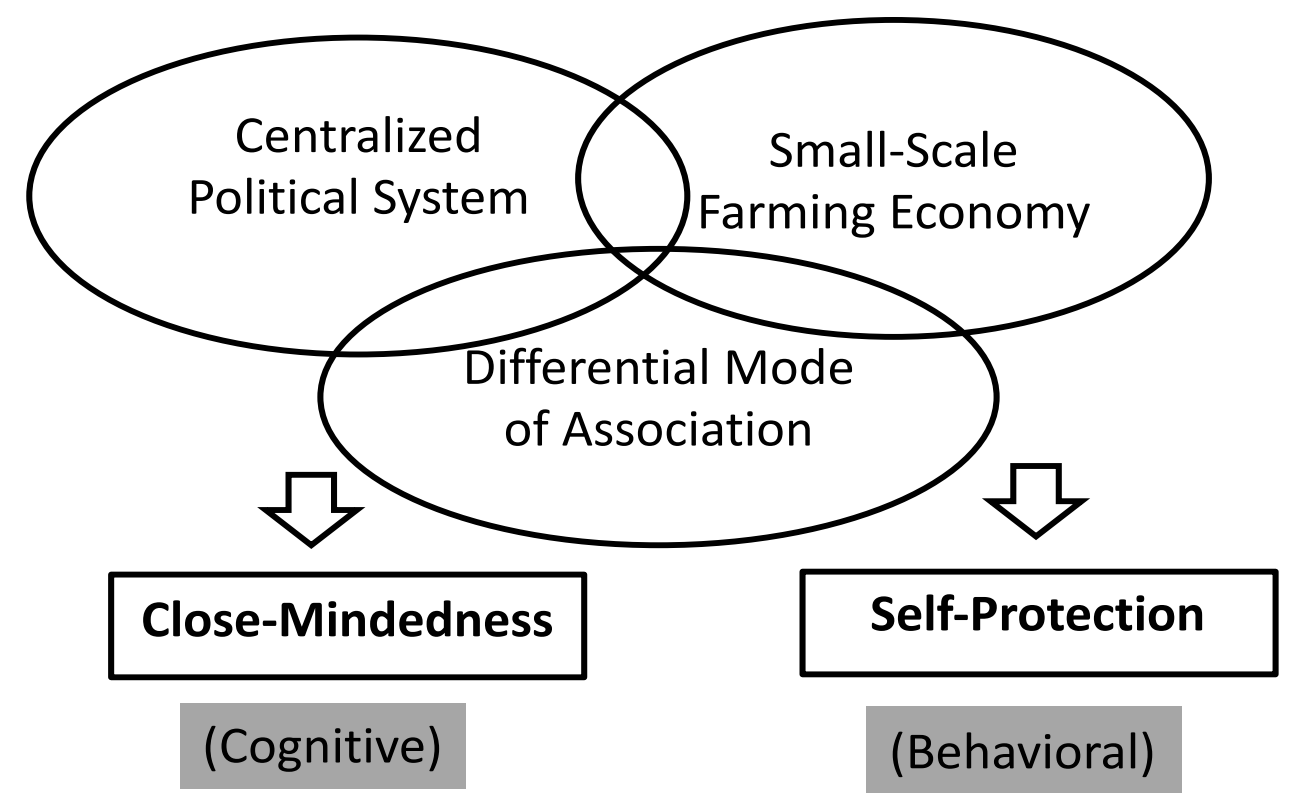

In-group

(Relational)

Out-Group
- Resistant to change

- Blind trust

- Content with minimal standards

- Pursue short-term gains

- Search for shortcuts

- Out-group distrust
- Passive communication

- Reckless decision making
- Maximize self-benefits

- Unwilling to share

- Lack of social participation

- Disregard common laws 


\section{Figure 3 Exemplary Coding Process on Outcomes of Parochialism in Chinese Firms' Globalization}

$1^{\text {st }}$ order themes

Low trust and empowerment toward employees guanxi-based hiring and promotion practices Limited investment in employee development

Passive communication reduced transparency Limited sharing and learning

Ambiguous communication caused

misinterpretation

Lack of quality precision and consistency Limited trust and collaboration with foreign partners

Indulgence in face-driven risk taking without due diligence

Falsified information

Lack of commitment to corporate social responsibility

Overlook local legal and environmental requirements

Less interested in building relationships with local communities

Remain status quo

Lack of strategic vision

Lack of innovation

Copy or counterfeit $2^{\text {nd }}$ order categories Aggregate dimensions

$2^{\text {nd }}$ order categories

Blinded trust towards in-group members

Content with minimal standards

Resistant to change

Passive communication

Reckless decision-making

Out-group distrust

Pursue short-term gains

Search for shortcuts

Strategic Planning
and Innovation

Customer

Orientation

Social

Responsibility
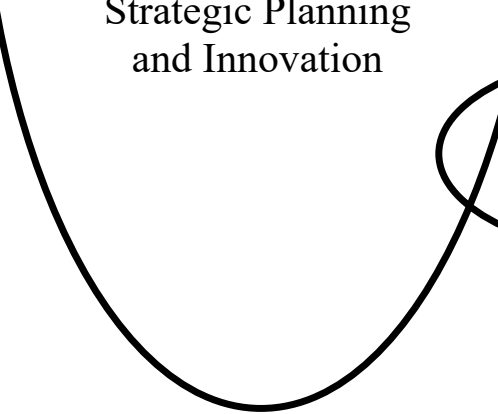

Notes: The overlap between circles represents the manifestation of parochialism through organizational cultures 
Parochialism in China 